\title{
Plasminogen Activator Inhibitor
}

National Cancer Institute

\section{Source}

National Cancer Institute. Plasminogen Activator Inhibitor. NCI Thesaurus. Code C16997.

A member of the serpin family of serine protease inhibitor proteins that inhibits plasminogen activator type proteases. 